\title{
VEHICLE DELAY AT THE CROSSROADS AND ROAD JUNCTIONS
}

\section{ЗАТРИМКИ ТРАНСПОРТНИХ ЗАСОБІВ НА ПЕРЕХРЕЩЕННЯХ ТА ПРИМИКАННЯХ АВТОМОБІЛЬНИХ ДОРІГ}

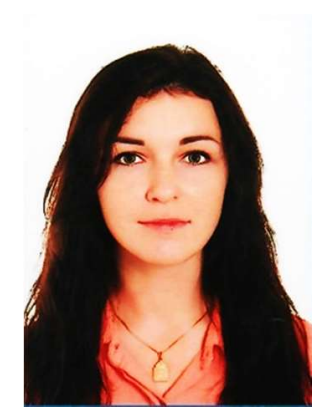

\author{
Sokolenko Tetiana Viktorivna, National Transport University, Department of \\ Road Designing, Geodesy and Land Management, postgraduate student, iamta- \\ nyxa@gmail.com,+380937875015
}

https://orcid.org/0000-0003-1485-2717

Summary. The main types of maneuvers on crossings and adjoints of highways in one level are studied. The probability of an unobstructed injection of a vehicle from a secondary to the main road and vice versa, taking into account the average length of the free interval between the vehicles of the main stream, is determined. The dependence of the duration of free intervals, and their number, on the intensity of traffic, the composition of the traffic flow, and the speed of vehicles, was found. A series of equations was obtained for determining the total transport delay in the performance of various types of maneuvers, depending on the type of intersection or adjacency. Vehicle delays at crossings and adjacent roads are used to economically justify changing their parameters. Therefore, the work is designed to minimize the delays of vehicles at crossings and interconnections both in one and at different levels.

Key words: road, maneuver, free interval, car, delay.

Introduction. The economic justification for the reconstruction of the highway is based on the time of unhindered passage of the road section. The study takes into account vehicle delays not only along the main road, but also on secondary roads, which makes it possible to more accurately describe the flow of traffic. In determining the delays at crossings and adjacencies, a reduction in the speed, stop, waiting time and travel without delay during vehicle maneuvers are taken into account, and these data are subsequently used to economically substantiate the change of cross-linking and adjacent parameters. Existing methods only consider the reduction of the speed of the entrance to the intersection or the adjoining, with its subsequent increase when you go to the main road. They do not take into account the travel of vehicles with a stop and expectations for maneuvering. In order to more accurately determine the time of car delay, intersections and adjoints, it is necessary to take into account not only the intensity and change of speed, but also precisely understand the pattern which vehicle makes and take into account the time spent as a change in speed when performing maneuvers, and on expectations Possibility of filling the injection into the main transport stream. To calculate the average delay in transport on the adjacency or intersection of roads it is very important to take into account time intervals between cars and groups of cars moving by the main stream. Since the availability of free intervals depends on the vehicle's ability to perform the maneuver, that is expected.

Objectives and Methods. For a more precise definition of the delay time of vehicles at the intersections and adjacencies of highways, one must investigate: the traffic flow, both on the main road and on the secondary one; the average length of movement of groups of cars along the main road and the time intervals with which vehicles proceeding on a secondary road. Record the number of cars waiting to be maneuvered and the number of cars passing without delay. The task is to get a dependency to calculate the waiting time of the car before maneuvering, taking into account the type of adjoining or intersection and the type of maneuver. 
Results and Explication. Delay arises when performing maneuvers by vehicles at adjacency and intersections as a result of insufficient length of the free interval. The main condition for a free travel without delay is the availability of free intervals between groups of cars moving along the main road. The free intervals should be sufficient for maneuvering.

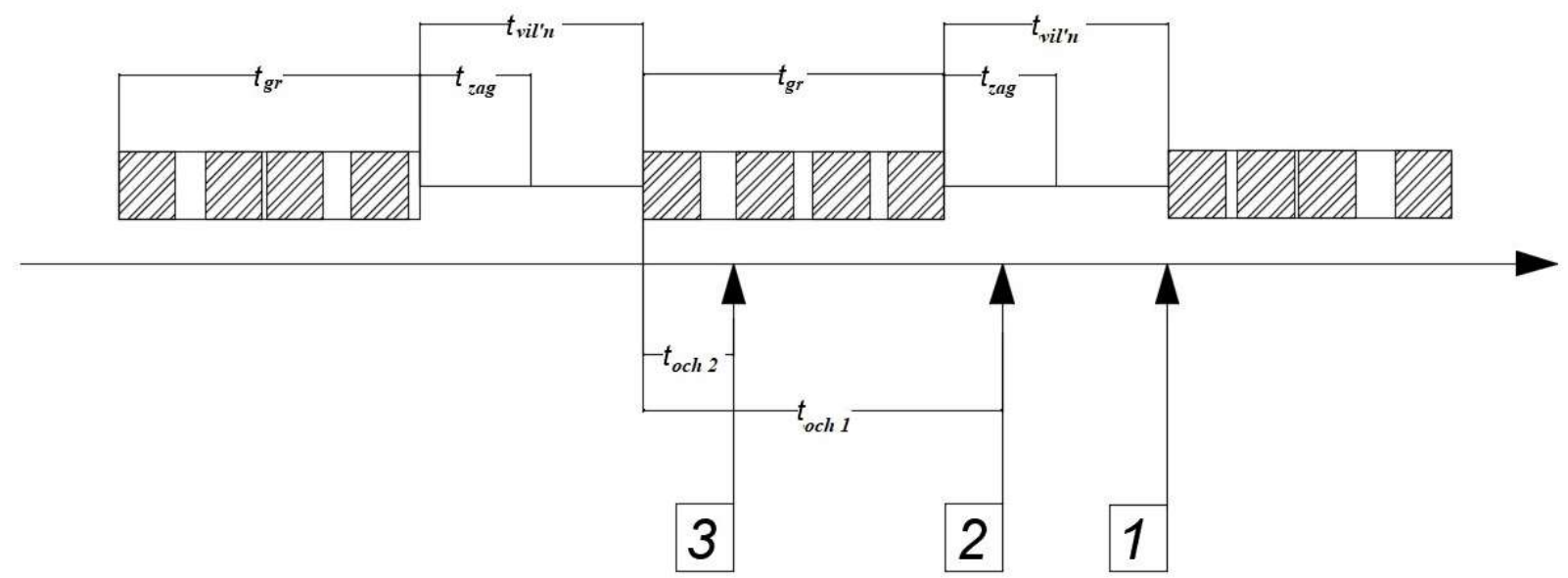

Figure 1 - The scheme of infusion of vehicles from the secondary road into the main stream of the main road: $\left(t_{g r}\right)$ travel time of a group of vehicles, seconds. $\left(t_{z a g}\right)$ time required for maneuvering, seconds. $\left(t_{v i l}{ }^{\prime}\right) d u-$ ration of the free interval, seconds. $\left(\mathrm{t}_{\text {och1 }}\right)$ waiting time for the vehicle's maneuver №2, seconds. $\left(\mathrm{t}_{\text {och } 2}\right)$ waiting time for maneuver of vehicle number 3 (1) vehicle number 1 (2) vehicle number 2 (3) vehicle number 3

Рисунок 1 - Схема вливання транспортних засобів із другорядної дороги в основний потік головної дороги: ( $\left.\mathrm{t}_{\mathrm{gr}}\right)$ час у дорозі групи транспортних засобів, секунд. $\left(\mathrm{t}_{\mathrm{zag}}\right)$ час, необхідний для маневрування, секунди. $\left(\mathrm{t}_{\mathrm{vil}} \mathrm{n}\right)$ тривалість вільного інтервалу, секунд. $\left(\mathrm{t}_{\mathrm{och}}\right)$ час очікування для маневру транспортного засобу №2, секунд. ( $\left.\mathrm{t}_{\mathrm{och} 2}\right)$ час очікування для маневру транспортного засобу № 3 (1) транспортного засобу № 1 (2) транспортного засобу № 2 (3) транспортного засобу №3

In Figure 1, there are three cases of injection of cars from the secondary road into the main stream of the main road. In the first case, car number 1 has enough time to perform maneuvers and travels without delay. In the second case, the time to carry out the maneuver by car number 2 is not enough, so the waiting time of the car will be $t_{\text {och1. }}$. In the third case for car number 3 , waiting time for a car for maneuver is $t_{\text {och2 }}$. The waiting time for the car is partly from the $t_{\text {zag }}$ and the driving time of the car group tgr. In option 3 , waiting time will be a part of the time from the $t_{\mathrm{gr}}$.

The car that drives to the adjacency is waiting for the time interval on the main road to be sufficient to perform the maneuver (freeman $\left.\left(t_{\mathrm{zag}}+\mathrm{t}_{\mathrm{gr}}\right)\right)$. In the event that the condition $\left(\mathrm{t}_{\mathrm{vil}} \mathrm{n}>\left(\mathrm{t}_{\mathrm{zag}}+\mathrm{t}_{\mathrm{gr}}\right)\right)$ is not executed, there is a delay of vehicles and a queue is formed. The ratio $\left(t_{\mathrm{zag}}+\mathrm{t}_{\mathrm{gr}}\right) /$ ton shows the share of fate on the number of cars on the secondary road (N2), which can wait until the maneuver. The total delay includes both time for maneuver and time spent on braking before maneuvering. While the timing of the maneuver in turn consists directly from the very maneuver and subsequent acceleration of the car to the required speed of movement:

$$
\mathrm{t}_{\mathrm{zag}}=t_{k r}+t_{\text {rozg }}
$$

where $t_{\mathrm{kr}}$ - time spent by the car, to travel through the curve of the area of adjoining.

$t_{\text {rozg }}$ - time of acceleration of the car to speed on the main road. There is a condition: the greater the intensity of the movement, the less free intervals. 


$$
t_{v i l, n}=f(N, c, V)
$$

where $\mathrm{N}$ - intensity of movement;

$\mathrm{c}$ - the structure of the traffic flow;

$\mathrm{V}$ - average speed on the main road.

Therefore, traffic on the main road will be characterized by the presence of free intervals and driving group of vehicles

The intensity will be:

$$
\mathrm{N}_{1}=\mathrm{n}_{\mathrm{gr}} \mathrm{n}_{\text {cars }}
$$

where $\mathrm{n}_{\mathrm{gr}}$ - number of groups of vehicles moving along the main road per unit time, pcs .;

$\mathrm{N}_{\text {cars }}$ - the number of vehicles in the group, vehicle.

Average travel time for 1 group of vehicles:

$$
\bar{t}_{g r}=\bar{t}_{c a r s} \cdot n_{\text {cars }}
$$

where $\bar{t}_{\text {cars }}$ - average interval of 1 vehicle, c .;

$\mathrm{n}_{\text {cars }}-$ number of vehicles in a group, pes.

Average free time interval:

$$
\bar{t}_{v i l n}=\frac{3600}{n_{g r}}-\bar{t}_{\mathrm{gr}}
$$

where $t_{\mathrm{gr}}$ - average length of movement of 1 group of vehicles, $\mathrm{s}$;;

$\mathrm{n}_{\text {group }}$ - the number of groups of vehicles going through the lane per unit time, pc.

To determine the transport delay, when performing any maneuver on the intersection or adjacency, the number of vehicles waiting for the maneuver is determined:

$$
N_{z a t r}=\frac{t_{z a g}+\bar{t}_{g r}}{\bar{t}_{v i l \prime n}} \cdot N_{2}=\frac{t_{z a g}+\bar{t}_{g r}}{\frac{3600}{n_{g r}}-\bar{t}_{\mathrm{gr}}} \cdot N_{2}=\frac{n_{g r} N_{2}\left(t_{z a g}+\bar{t}_{g r}\right)}{3600-\bar{t}_{\mathrm{gr}} \cdot n_{g r}}
$$

where $\mathrm{N}_{2}$ - intensity of traffic on a secondary road, vehicles / year;

$\mathrm{N}_{1}$ - intensity of movement on the extreme right lane of the main road, vehicles / hour;

$\mathrm{t}_{\mathrm{zag}}$ - time required for maneuvering, sec.

$t_{g r}$ - average time of the group of vehicles, sec.

The vehicle can drive to the adjacency at any time interval within 0 - $\left(\right.$ tgeneral $\left.+t_{\mathrm{gr}}\right)$. The maximum delay of the transport will be when, at the time of arrival to the adjacency, the value of the free time interval on the main road will be approximated to 0 . The minimum delay of the transport will be when the value of the free interval will be close to $\left(\mathrm{t}_{\mathrm{zag}}+\mathrm{t}_{\mathrm{gr}}\right)$.

The total delay in transport, when performing any maneuver, will be equal to:

$$
t_{z a t r}=n_{z a t r} \cdot \frac{t_{z a g}+t_{g r}}{2}=\frac{n_{g r} N_{2}\left(t_{z a g}+\bar{t}_{g r}\right)}{3600-{ }^{-}{ }_{\text {gr }} \cdot n_{g r}} \cdot \frac{t_{z a g}+\bar{t}_{g r}}{2}=\frac{n_{g r} N_{2}\left(t_{z a g}+\bar{t}_{g r}\right)^{2}}{7200-\cdot \bar{t}_{g r} \cdot n_{g r}}
$$


where $\frac{t_{z a g}+t_{g r}}{2}$ - the average duration of delay, sec .;

$n_{z a t r}-$ number of vehicles waiting for the maneuver, pcs;

$\mathrm{N}_{1}$ - intensity of movement on the extreme right lane of the main road, vehicles / hour;

$\mathrm{N}_{2}$ - intensity of traffic on a secondary road, vehicles / hour;

$t_{\text {zag }}$ - time required for the maneuver, sec;

$\bar{t}_{\text {gr }}$ - average length of the journey of a group of vehicles, sec.

The general delay of transport, when performing the maneuver of the vehicles from the secondary to the main road, will be equal to:

$$
t_{z a t r}=\frac{n_{g r} N_{2}\left(t_{z a g}+\bar{t}_{g r}\right)^{2}}{7200-2 \cdot \bar{t}_{g r} \cdot n_{g r}}
$$

where $n_{g r}$ is the number of groups of vehicles going through the lane per unit time, pcs ;

$\mathrm{N}_{2}$ - intensity of traffic on a secondary road, vehicles / hour;

$\mathrm{t}_{\mathrm{zag}}$ - time required for maneuvering, sec.;

$\bar{t}_{\text {групи }}$ average length of driving of a group of vehicles, sec.

Let's consider three cases of a maneuver of the right turn from the secondary road to the main one. Figure 2 shows the scheme of the vehicle when performing the maneuver of the right turn from the secondary road to the main without delay.

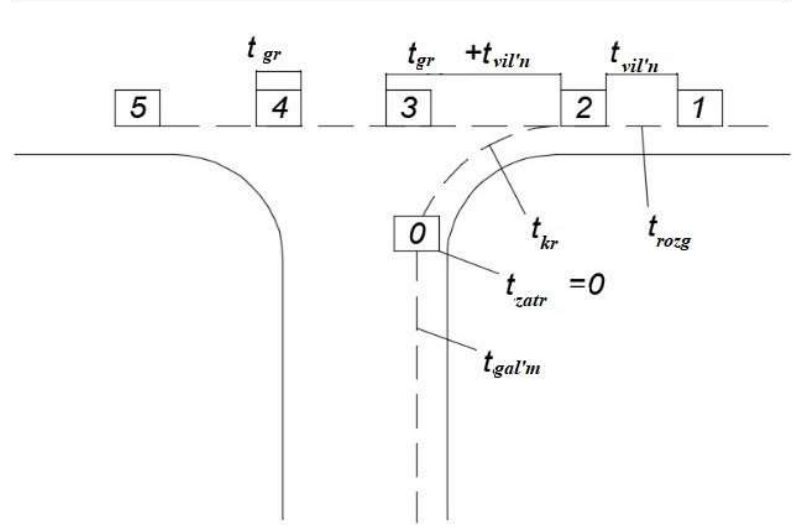

Figure 2 - Scheme of vehicle movement when performing the maneuver of the right turn from the secondary road to the main without delay: $\mathrm{t}_{\mathrm{gr}}$ - average length of movement of 1 group of vehicles, $\mathrm{s}$

Рисунок 2 - Схема руху транспортного засобу при виконанні маневру правого повороту від другорядної дороги до головної без затримок: $\mathrm{tgr}_{\mathrm{gr}}$ середня довжина руху 1 групи транспортних засобів, с

Figure 3 shows the scheme of movement of the vehicle when performing the maneuver of the right turn from the secondary road to the main with a minimum loss of time: 


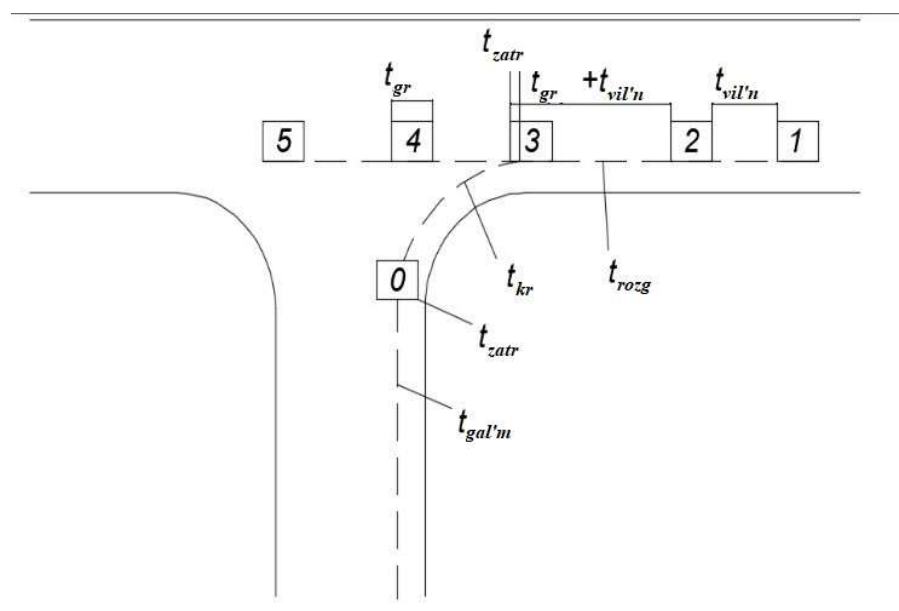

Figure 3 - Scheme of vehicle movement when performing the right turn maneuver from the secondary road to the main with a minimum loss of time

Рисунок 3 - Схема руху транспортного засобу при виконанні маневру правого повороту від другорядної дороги до основної з мінімальними втратами часу

Figure 4 shows the scheme of the vehicle movement when performing the right turn maneuver from the secondary road to the main with the maximum delay value:

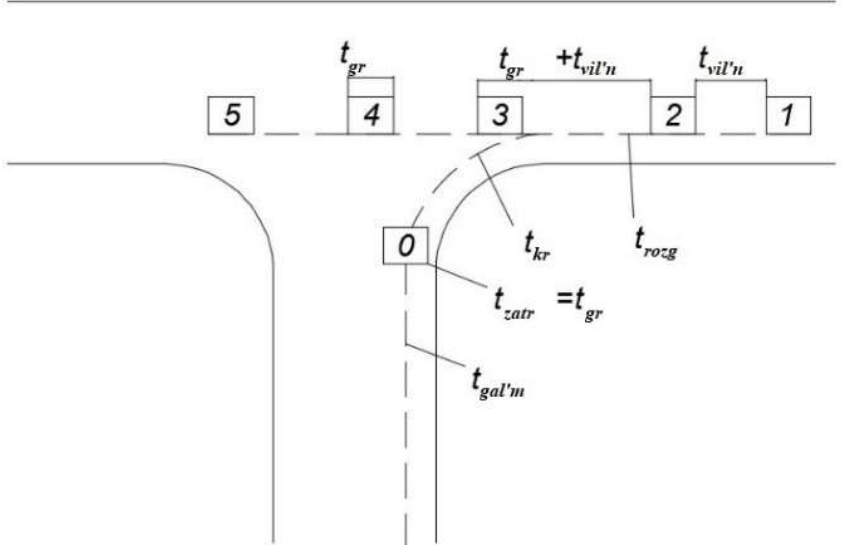

Figure 4 - Scheme of car movement when performing the right turn maneuver from the secondary road to the main with the maximum value of delay

Рисунок 4 - Схема руху автомобіля при виконанні маневру правого повороту від другорядної дороги до головної з максимальним значенням затримки

General delay of transport, when performing the maneuver of the right turn from the secondary road to the main, is determined with the formula:

$$
t_{z a t r}=\frac{n_{g r} N_{2}\left(t_{z a g 1}+\bar{t}_{g r}\right)^{2}}{7200-\cdot \bar{t}_{g r} \cdot n_{g r}}
$$

where $\mathrm{n}_{\mathrm{gr}}$ - number of groups of cars going through the lane per unit time, pcs .;

$\mathrm{N}_{2}$ - intensity of traffic on a secondary road, vehicles / hour;

$\mathrm{t}_{\mathrm{zag} 1}$ - total time required for maneuvering the right turn from the secondary road to the main, sec .;

$\bar{t}_{\text {gr }}$ - average length of driving of a group of vehicles, sec. 
Figure 5 shows the scheme of the vehicle movement when performing the right turn maneuver from the main road to the secondary without a delay:

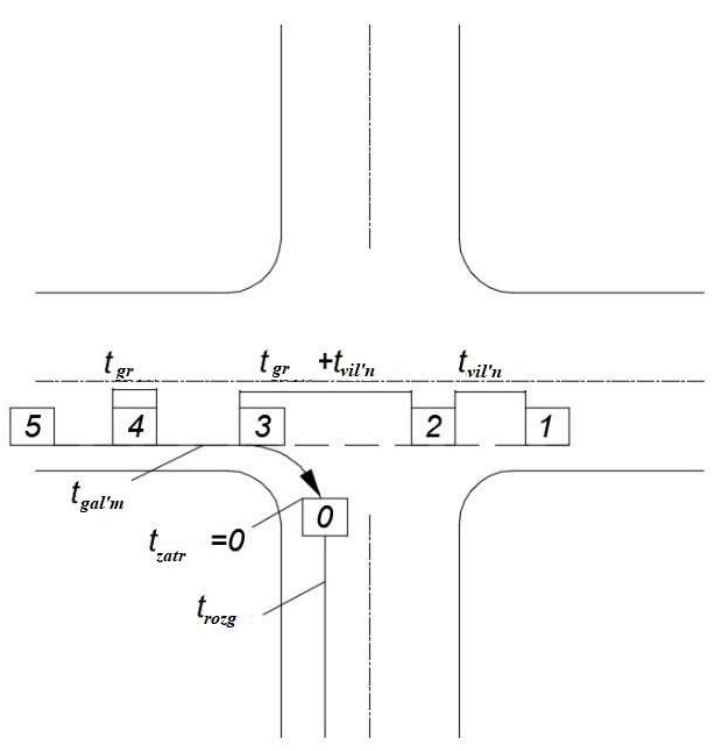

Figure 5 - Scheme of the vehicle movement when performing the right turn maneuver from the main road to the secondary without delay

Рисунок 5 - Схема руху транспортного засобу при виконанні маневру правого повороту з головної дороги на вторинну без затримок

General delay of transport, when performing the right turn maneuver from the main road to the secondary, is determined by the formula:

$$
t_{z a t r}=\frac{n_{g r} N_{2}\left(t_{z a g 2}+\bar{t}_{g r}\right)^{2}}{7200-2 \cdot \bar{t}_{g r} \cdot n_{g r}}
$$

where $\mathrm{n}_{\mathrm{gr}}$ - number of groups of vehicles going through the lane per unit time, pcs.;

$\mathrm{N}_{2}$ - intensity of traffic on a secondary road, vehicles / hour;

$t_{\text {all }}$ - total time required to perform the right turn maneuver from the main road, sec.

$t_{\mathrm{gr}}$ - average length of driving of a group of vehicles, sec.

The delay of the transport on the intersection, when performing the maneuver of the direct intersection of the main road flow is presented in Fig. 6. 


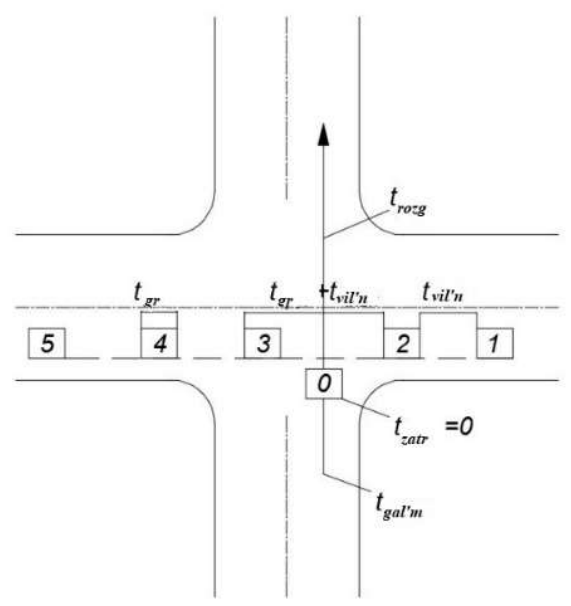

Figure 6 - The scheme of movement of the vehicle when performing the maneuver of the direct intersection of the main road flow without delay

Рисунок 6 - Схема руху транспортного засобу при виконанні маневру прямого перехрестя основного дорожнього потоку без затримок

The general delay of transport, when performing the maneuver of the direct intersection of the main road flow, is determined by the formula:

$$
t_{z a t r}=\frac{n_{g r} N_{2}\left(t_{z a g 3}+\bar{t}_{g r}\right)^{2}}{7200-\cdot \bar{t}_{g r} \cdot n_{g r}}
$$

where $\mathrm{n}_{\mathrm{gr}}$ - number of groups of vehicles going through the lane per unit time, pcs .;

$\mathrm{N}_{2}$ - intensity of traffic on a secondary road, vehicles / hour;

$t_{\text {zag3 }}$ - total time required to perform the maneuver of the direct intersection of the main road flow, sec.

$\bar{t}_{\mathrm{gr}}$ - average length of driving of a group of vehicles, sec.

The number of vehicles traveling without stopping is calculated by the formula:

$$
n_{\text {б.з. }}=N_{2}-n_{\text {затр }}
$$

where $\mathrm{N}_{2}$ - intensity of traffic on a secondary road, vehicles / year;

$\mathrm{n}_{\mathrm{zatr}}$ - number of vehicles that are waiting for maneuver, pcs.

Conclusions and recommendations: The results of the research presented in the article are theoretically and practically substantiated, tested in real conditions. When solving the problems of reducing the overload of crossings and adjacencies of highways in one or more levels, it would be reasonable to use the resulting research formulas to calculate the delay.

\section{References}

1. Crossing and adjoining roads in one level. Methods of designing and organizing traffic. VBN V.2.3218-192-2005. Ukravtodor K., 2005.

2. VA Hoffman, VM Vizgalov, MP Polyakov. Crossing and adjoining roads. - M.: Higher school, 1989. $-319 \mathrm{p}$.

3. Keit F. Mathematical theory of transport flows. Moscow, Mir Publ., 1966.

4. Polishchuk VP, Dzyuba O.P. The theory of transport flow: methods and models of road traffic organization / VP Polishchuk, O.P. Dzyuba - K .: Knowledge of Ukraine, 2008. - 175 p. 
5. Drew D. The theory of transport flows and their management. M .: Transport, 1972. - $424 \mathrm{p}$.

6. Polishchuk VP The theory of traffic flow: methods and models of traffic organization: teaching. manual / VP Polishchuk, O.P. Dzyuba - K .: Knowledge of Ukraine, 2008. - P. 49 - 169.

7. Designing and searching of intersections of highways / [E.M. Lobanov, V.M. Shevyakov, VA Gohman and others]. - M .: Transport, 1972. - P. 40-84.

8. Palchik AM Transport streams / Palchik AM - K .: NTU, 2010. - P. 26-42, 44-47, 52-54, 87-102.

\section{ЗАТРИМКИ ТРАНСПОРТНИХ ЗАСОБІВ НА ПЕРЕХРЕЩЕННЯХ ТА ПРИМИКАННЯХ АВ- ТОМОБІЛЬНИХ ДОРІГ}

Соколенко Тетяна Вікторівна, Національний транспортний університет, кафедра проектування доpiг, геодезії та землеустрою, аспірант, iamtanyха@gmail.com, +380937875015, https://orcid.org/00000003-1485-2717.

Анотація: Досліджено основні види маневрів на пересіченнях та примиканнях автомобільних доріг в одному рівні. Визначено імовірність безперешкодного вливання автомобіля з другорядної дороги на головну і навпаки, з урахуванням середньої тривалості вільного інтервалу між автомобілями основного потоку. Знайдено залежність тривалості вільних інтервалів, та їх кількість, від інтенсивності руху, складу транспортного потоку, швидкості руху автомобілів. Отримано ряд рівнянь для визначення загальної затримки транспорту при виконанні різних видів маневрів в залежності від типу пересічення чи примикання. Затримки транспортних засобів на перехрещеннях та примиканнях автомобільних доріг використовуються для економічного обгрунтування зміни їх параметрів. Отже робота розрахована на мінімізацію затримок транспортних засобів на перехрещеннях і примиканнях як в одному так і в різних рівнях.

Ключові слова: дорога, маневр, вільний інтервал, автомобіль, затримка.

\section{Перелік посилань}

1. Перехрещення та примикання доріг в одному рівні. Методи проектування та організації дорожнього руху. ВБН В.2.3-218-192-2005. Укравтодор. К., 2005.

2. В. А. Гофман, В. М. Визгалов, М. П. Поляков. Пересечения и примыкания автомобильных дорог. - М. : Высшая школа, 1989. - 319 с.

3. Хейт Ф. Математическая теория транспортных потоков. М.: Мир, 1966. — 288 с.

4. Поліщук В.П., Дзюба О.П. Теорія транспортного потоку: методи та моделі організації дорожнього руху / В.П. Поліщук, О.П. Дзюба. - К.: Знання України, 2008. - 175 с.

5. Дрю Д. Теория транспортных потоков и управление ими. М.: Транспорт, 1972. - 424 с.

6. Поліщук В.П. Теорія транспортного потоку: методи та моделі організації дорожнього руху : навч. посіб. / В.П. Поліщук, О.П. Дзюба. - К.: Знання України, 2008. - С. 49 - 169.

7. Проектирование и изыскание пересечений автомобильных дорог / [ Е.М. Лобанов, В.М. Шевяков, В.А. Гохман и др. ]. - М.: Транспорт, 1972. - С. 40-84.

8. Пальчик А.М. Транспортні потоки / Пальчик А.М. - К.: НТУ, 2010. - С. 26-42, 44-47, 52-54, 87102. 